\title{
Erratum to: Case Report: Adrenal LH/hCG Receptor Overexpression and Gene Amplification Causing Pregnancy-Induced Cushing's Syndrome
}

\author{
Michael Herman Chui • Nese Colak Özbey • \\ Shereen Ezzat • Yersu Kapran • Yesim Erbil • \\ Sylvia L. Asa
}

Published online: 3 December 2009

(C) Springer Science+Business Media, LLC 2009

\section{Erratum to: Endocr Pathol (2009) 20:256-261}

DOI 10.1007/s12022-009-9090-2

The original version of this article unfortunately contained a mistake. The last name of Michael Herman Chui was not listed correctly. The correct last name is shown below.

The online version of the original article can be found at http://dx.doi. org/10.1007/s12022-009-9090-2.

M. H. Chui $\cdot$ S. L. Asa $(\bowtie)$

Department of Pathology, University Health Network,

200 Elizabeth Street, 11th Floor,

Toronto, ON, Canada M5G 2C4

e-mail: sylvia.asa@uhn.on.ca

\section{N. C. Özbey}

Division of Endocrinology, Department of Internal Medicine,

Istanbul Faculty of Medicine, Istanbul University,

34390 Capa, Istanbul, Turkey

\section{S. Ezzat}

Department of Medicine, Division of Endocrinology,

University Health Network and Mount Sinai Hospital,

Toronto, ON, Canada

\section{Y. Kapran}

Department of Pathology, Istanbul Faculty of Medicine,

Istanbul University,

34390 Capa, Istanbul, Turkey

\section{Y. Erbil}

Department of Surgery, Istanbul Faculty of Medicine, Istanbul University,

34390 Capa, Istanbul, Turkey 